\title{
Angiopoietin-1 modulates endothelial cell function and gene expression via the transcription factor FKHR (FOXO1)
}

\author{
Christopher Daly, ${ }^{1}$ Vivian Wong, Elena Burova, Yi Wei, Stephanie Zabski, Jennifer Griffiths, \\ Ka-Man Lai, Hsin Chieh Lin, Ella Ioffe, George D. Yancopoulos, and John S. Rudge \\ Regeneron Pharmaceuticals, Inc., Tarrytown, New York 10591, USA
}

\begin{abstract}
Despite genetic evidence establishing angiopoietin-1 (Ang-1) as an essential regulator of vascular development, the molecular mechanisms underlying Ang-1 function are almost completely uncharacterized. In this report, we demonstrate that Ang-1, via Akt activation, is a potent inhibitor of the forkhead transcription factor FKHR (FOXO1), identifying for the first time a nuclear signaling pathway through which Ang-1 modulates gene expression. We use microarray analysis to show that FKHR, whose function in endothelial cells has not previously been elucidated, regulates many genes associated with vascular destabilization and remodeling (including angiopoietin-2, an Ang-1 antagonist) and endothelial cell apoptosis (e.g., survivin, TRAIL). Ang-1 inhibits FKHR-mediated changes in gene expression and FKHR-induced apoptosis. Analysis of gene expression changes induced by an activated version of Akt confirms that FKHR is a major target through which Akt regulates transcription in endothelial cells. We use RNA interference to demonstrate that FKHR is required for the expression of genes (including Ang-2) that have important vascular functions. Our data suggest a novel, tissue-specific role for the Akt/FKHR pathway in the vasculature and suggest a mechanistic basis for the previously described actions of Ang-1 as a regulator of endothelial cell survival and blood vessel stability.
\end{abstract}

[Keywords: Ang-1; FKHR; Akt; endothelial cell]

Supplemental material is available at http://www.genesdev.org.

Received January 28, 2004; revised version accepted March 24, 2004.

Genetic analysis has established that the receptor tyrosine kinase Tie2 and its activating ligand Ang-1 are required for vascular development (Sato et al. 1995; Davis et al. 1996; Suri et al. 1996). In particular, the phenotype of Ang-1 null embryos suggests a role for Ang-1 in stabilizing the interactions between endothelial cells and surrounding support cells and/or extracellular matrix (Suri et al. 1996). In addition to its role in vascular development, the presence of phosphorylated Tie2 in several adult tissues suggests an ongoing role for Ang-1 in mature vessels (Wong et al. 1997), perhaps as an endothelial cell survival factor (Kim et al. 2000; Papapetropoulos et al. 2000; Jones et al. 2001) or as an antileak agent (Thurston et al. 1999). However, the molecular mechanisms through which Ang-1 works remain almost completely uncharacterized. In particular, only one Ang1-regulated gene (survivin) has been identified (Papapetropoulos et al. 2000), and there are no data regarding signaling pathways through which Ang-1 modulates transcription.

${ }^{1}$ Corresponding author.

E-MAIL christopher.daly@regeneron.com; FAX (914) 347-5045.

Article and publication are at http://www.genesdev.org/cgi/doi/10.1101/ gad.1189704.
Although Ang-1 has been shown to promote survival of endothelial cells in vitro via the phosphatidylinositol 3-kinase/Akt pathway (Kim et al. 2000; Papapetropoulos et al. 2000), the relevant downstream targets of Akt have not been identified. Akt substrates that might mediate its effects on endothelial cells include the FOXO subclass of forkhead transcription factors FKHR (FOXO1), FKHRL1 (FOXO3a), and AFX (FOXO4). Phosphorylation of FOXO proteins by Akt occurs at three conserved sites and results in inhibition of FOXO function by promoting FOXO nuclear export (Biggs et al. 1999; Brunet et al. 1999, 2002) and/or by inhibiting FOXO DNA binding (Zhang et al. 2002). Current models propose that FOXO proteins are activated in response to cell stress and function to promote an adaptive response, or, if the stress is severe, an apoptotic response (Burgering and Medema 2003; Tran et al. 2003). For example, FOXO proteins have been shown to promote cell cycle arrest, resistance to oxidative stress, DNA repair, hepatic glucogenesis, and apoptosis (Burgering and Medema 2003; Tran et al. 2003). Although recent reports suggest a role for FOXO3a in endothelial cell apoptosis (Skurk et al. 2003), and that vascular endothelial cell growth factor (VEGF) can block FOXO-dependent killing (Abid et al. 2004), the function of FOXO proteins in endothelial cells has not been stud- 
ied in detail. Interestingly, a recent study shows that FOXO1 (FKHR) null embryos (but not FOXO3a or FOXO4 null embryos) exhibit defects in vascular development, indicating that FKHR plays an important role in blood vessels (Hosaka et al. 2004).

In this report we demonstrate that FKHR is a mediator of Ang-1-induced transcriptional changes in primary endothelial cells, and that in addition to regulating the expression of genes relevant to apoptosis, FKHR regulates the expression of many genes (including the Ang-1-antagonist Ang-2) associated with vascular destabilization and remodeling. Thus, in addition to suggesting a novel function for FKHR in blood vessels, our data suggest a molecular mechanism through which Ang-1 may function to promote vascular stability.

\section{Results}

To investigate the possibility that Ang-1 regulates the activity of FOXO transcription factors, we used bovine lung microvascular endothelial cells (MVECs), a cell type in which Ang-1 elicits strong signaling responses (Papapetropoulos et al. 2000). Because endothelial cells appear to express mainly FKHR, rather than FKHRL1 or AFX (data not shown), we chose to focus on FKHR. MVECs were stimulated with Ang-1 as well as with VEGF and basic fibroblast growth factor (bFGF), two growth factors that modulate endothelial cell function in different ways than Ang-1. For example, VEGF, unlike
Ang-1, promotes endothelial cell proliferation in vitro and induces vessel sprouting as opposed to vessel maturation in vivo (Yancopoulos et al. 2000). Following treatment for the indicated times, cell lysates were prepared and subjected to immunoblot using phospho-specific antibodies against Akt, ERK 1/2, and FKHR (Fig. 1A). Both VEGF and bFGF induced phosphorylation of Akt at Ser 473 (indicative of Akt activation), although to a significantly lesser extent than did Ang-1 (Fig. 1A; Ang-1 also promoted phosphorylation of Akt at Thr 308; Supplementary Fig. S1). The robust activation of Akt by Ang-1 was accompanied by a marked induction of FKHR phosphorylation at Thr 24 and at Ser 256 (Fig. 1A), two phosphorylation sites that are essential to Akt-mediated inhibition of FKHR function (Brunet et al. 1999). In contrast, the phosphorylation of FKHR in response to VEGF or bFGF was much weaker (Fig. 1A). The stronger activation of the Akt/FKHR pathway by Ang-1 does not simply reflect the fact that Ang-1 is in general a more potent stimulator of signaling responses in MVECs, given that bFGF activated ERK phosphorylation to a significantly greater extent than did Ang-1, whereas VEGF activated ERK to about the same extent as did Ang-1 (Fig. 1A). Thus, Ang-1 is a strong activator of the Akt pathway, relative to VEGF and bFGF, suggesting that Ang-1 is likely to be the major regulator of FKHR function in endothelial cells.

Akt-mediated phosphorylation of FKHR is thought to inhibit FKHR function by promoting its export from the
A

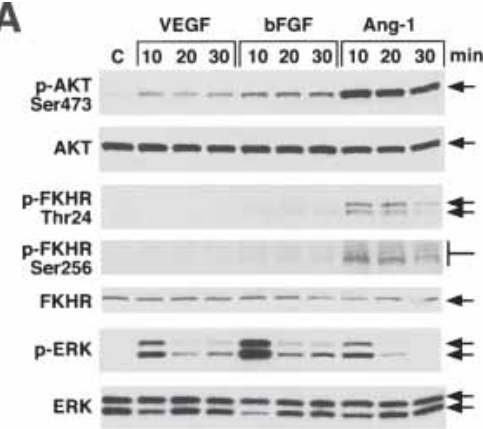

B

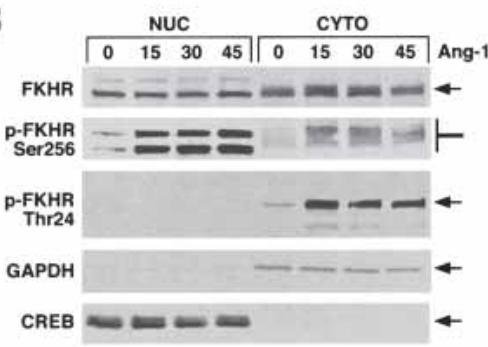

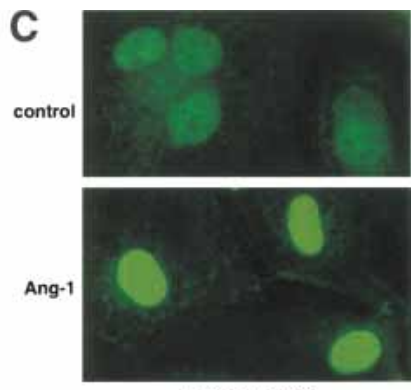

p-FKHR Ser256

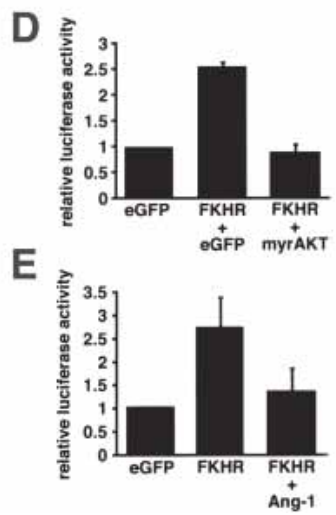

Figure 1. Angiopoietin-1-mediated phosphorylation and functional inhibition of FKHR in primary endothelial cells. (A) MVECs were serum-starved for $1 \mathrm{~h}$ and then either untreated or stimulated for the indicated times with VEGF, bFGF, or Ang-1. Cell lysates were subjected to Western blot with antibodies against phospho-Akt (Ser 473), Akt, phospho-FKHR (Thr 24 or Ser 256), FKHR, phospho ERK 1/2(Thr 202/Tyr 204) and ERK 1/2. (B) MVECs were serum-starved overnight and then either untreated or stimulated with Ang-1 for the indicated times. Cytoplasmic and nuclear fractions were prepared and subjected to Western blot with antibodies against phospho-FKHR (Thr 24 or Ser 256) or FKHR. Antibodies against GAPDH and CREB were used to validate the fractionation procedure. (C) MVECs were serum-starved overnight and then either untreated or stimulated with Ang-1 for 30 min. Following treatment, cells were fixed and stained with antibody against phospho-FKHR Ser 256. (D) MVECs were transfected with FHRE-Luc reporter plasmid along with plasmids encoding: eGFP, FKHR + eGFP, or FKHR + myrAkt. At $24 \mathrm{~h}$ after transfection, cell lysates were prepared and luciferase activity was measured. Bars show luciferase activity relative to eGFP control (assigned a value of 1.0). Bars represent the mean and S.E.M., $n=3$. (E) MVECs were transfected with FHRE-Luc reporter plasmid along with plasmids encoding either eGFP or FKHR. At $8 \mathrm{~h}$ after transfection, cultures expressing FKHR were either untreated or stimu-

lated with Ang-1. At 24 h, cell lysates were prepared and luciferase activity was measured. Bars show luciferase activity relative to eGFP control (assigned a value of 1.0). Bars represent the mean and S.D., $n=9$. The difference in luciferase activity between the FKHR and FKHR + Ang-1 samples was statistically significant by $t$-test, $p<0.001$. 
nucleus (Brunet et al. 1999, 2002) and/or by inhibiting DNA binding (Zhang et al. 2002). To test whether Ang1 -induced phosphorylation of FKHR is accompanied by a change in FKHR localization, nuclear and cytoplasmic fractions were prepared from Ang-1-treated MVECs and subjected to immunoblot with FKHR antibody as well as phospho-specific FKHR antibodies. As shown in Figure 1B, a 15-min treatment with Ang-1 induced a modest increase $(1.8$-fold) in the amount of FKHR in the cytoplasm. Strikingly, FKHR that was phosphorylated on Thr 24 was exclusively cytoplasmic (Fig. 1B), indicating that phosphorylation at this site is closely linked with nuclear exclusion. In contrast, FKHR phosphorylated on Ser 256 was largely (although not completely) nuclear at all times after treatment (Fig. 1B). Immunostaining of MVECs with antibody to phospho-FKHR Ser 256 confirmed this result, as Ang-1 induced a significant increase in staining, primarily in the nucleus (Fig. 1C). This suggests that phosphorylation of FKHR at Ser 256 is not sufficient to promote nuclear export; the cytoplasmic FKHR that is phosphorylated on Ser 256 might also be phosphorylated on Thr 24 or another residue(s) that promotes nuclear export. Thus, our data suggest that Ang-1-mediated inhibition of FKHR is not entirely dependent on exclusion of FKHR from the nucleus, consistent with a recent report showing that phosphorylation at Ser 256 inhibits FKHR binding to DNA (Zhang et al. 2002).

To assess whether Ang-1 can inhibit FKHR-mediated transcriptional activation, MVECs were transfected with a reporter plasmid in which luciferase expression is controlled by a promoter containing FKHR-binding sites
(Brunet et al. 1999). Cotransfection of a FKHR expression plasmid with the reporter plasmid resulted in a significant increase in luciferase expression (Fig. 1D,E), which was blocked by either coexpression of myrAkt (a version of Akt that gets myristoylated, associates with the plasma membrane, and is constitutively active; Kohn et al. 1996; Fig. 1D) or by treatment of transfected cultures with Ang-1 (Fig. 1E). These results indicate that Ang-1, in addition to inducing phosphorylation of FKHR, can inhibit FKHR-mediated transcriptional activation.

Although our data establish the existence of a signaling pathway through which Ang-1 inhibits FKHR, the function of FKHR in endothelial cells is unknown. One prominent function of FKHR in other types of mammalian cells appears to be the induction of apoptosis (Burgering and Medema 2003; Tran et al. 2003). To investigate the possibility that FKHR can induce apoptosis in endothelial cells, human umbilical vein endothelial cells (HUVECs) were infected with adenoviruses encoding either GFP or a mutant version of FKHR (FKHR-TM, or triple mutant; Brunet et al. 1999) in which the Akt sites were changed to alanine, which is therefore not subject to inhibition via the Akt pathway. At 24, 32, or $48 \mathrm{~h}$ after infection, the induction of apoptosis was assessed by immunoblot for the cleaved (active) form of caspase-3, a specific biochemical marker of apoptosis. As shown in Figure 2A (top panel), expression of FKHR-TM, but not GFP, resulted in the generation of active caspase- 3 at 32 and $48 \mathrm{~h}$ after infection, with a large increase in the level of active caspase- 3 occurring between 32 and 48 h. Importantly, expression of a deletion mutant of FKHR containing just the DNA-binding domain (FKHR-DB) failed
Figure 2. Angiopoietin-1 inhibits FKHR-induced apoptosis in endothelial cells. ( $A$, top panel) HUVECs were infected with adenoviruses encoding either GFP or FKHR-TM. At 24, 32, or $48 \mathrm{~h}$ after infection, cell lysates were prepared and subjected to Western blot with antibodies against myc tag (detects virally encoded FKHRTM), GFP, active caspase-3, or ERK (as a loading control). (Bottom panel) HUVECs were infected with adenoviruses encoding either FKHR-DB or FKHR-TM for 24 or $48 \mathrm{~h}$. Cell lysates were prepared and subjected to Western blot with antibodies against myc tag (detects both FKHR-TM and FKHR-DB), active caspase-3 or ERK. (B) HUVECs were infected with adenoviruses encoding either GFP or FKHR-TM for $32 \mathrm{~h}$. Cells were fixed and nuclear morphology was assessed by staining with Hoechst 33342. Arrows indicate apoptotic nuclei. (C) HUVECs were infected with adenoviruses encoding either GFP, FKHR, or FKHR-TM for 24, 32, or $45 \mathrm{~h}$. At each time point the relative number of living cells was determined by MTS assay. The data points represent the number of living cells relative to the GFP control cultures (assigned a value of 1.0). Each data point is the mean and S.D. of three experiments. $(D)$ MVECs were infected with adenoviruses encoding either GFP or FKHR. At 9, 22, and $30 \mathrm{~h}$ after infection, FKHR expressing cultures were either untreated or stimulated with Ang-1. At $48 \mathrm{~h}$ after infection, the relative number of viable cells was determined by MTS assay. The bars represent the mean and S.D., $n=6$. The difference in the number of viable cells between the FKHR and the FKHR + Ang-1 cultures was statistically significant by $t$-test, $p<0.005$.
A
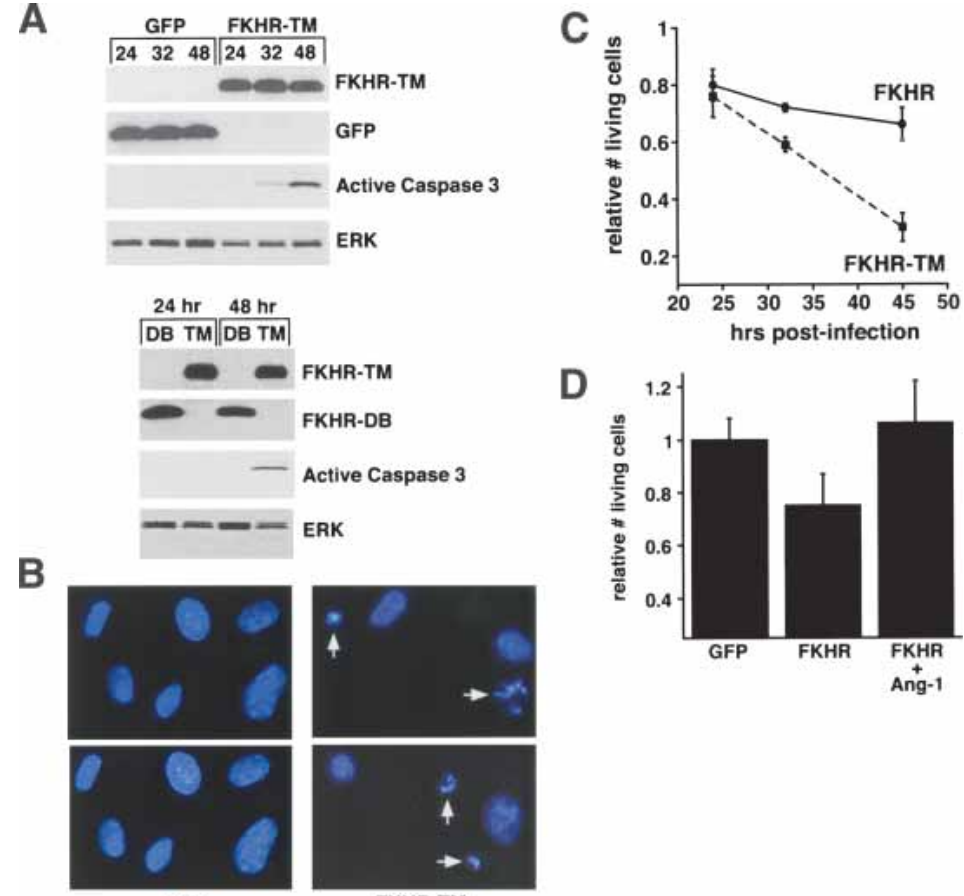

D

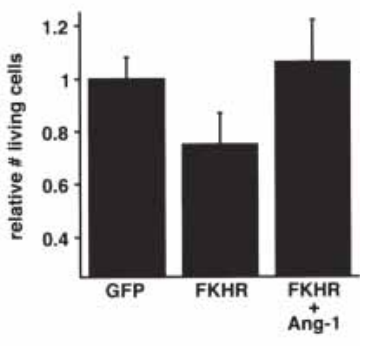

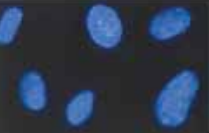

GFP
FKHR-TM 
to induce caspase- 3 activation, demonstrating that induction of apoptosis by FKHR requires the transcriptional activation domain (Fig. 2A, bottom panel). To confirm the induction of apoptosis by FKHR-TM, the nuclear morphology of cells expressing either GFP or FKHR-TM was assessed with Hoechst stain. At $32 \mathrm{~h}$ after infection, cultures expressing FKHR-TM had fewer adherent cells (because of detachment of apoptotic cells), and many of the remaining adherent cells exhibited condensed, fragmented nuclei, a hallmark of apoptosis (Fig. 2B). To quantitate the effect of FKHR on cell survival, HUVECs were infected with viruses encoding either GFP, FKHR, or FKHR-TM for 24, 32, or $45 \mathrm{~h}$, and the number of living cells was determined at each time point. As expected, FKHR-TM (which cannot be inhibited by basal Akt activity) had a much more dramatic effect on cell survival than did FKHR (Fig. 2C). Importantly, the FKHR-mediated reduction in the number of viable cells was blocked by Ang-1 treatment (Fig. 2D), indicating that in addition to inhibiting FKHR-mediated transcriptional activation (Fig. 1E), Ang-1 blocks FKHRdependent apoptosis.

Our data suggest that one function of FKHR in endothelial cells is to induce apoptosis. However, apoptosis may be just one of several downstream effects of FKHR activation. To gain insight into the full range of effects FKHR might have on endothelial cells, we sought to identify FKHR target genes using microarray technology. HUVECs were infected with adenoviruses encoding either FKHR-TM or GFP. At 12, 16, and $24 \mathrm{~h}$ after infection, RNA was isolated and used to prepare labeled cDNA samples for microarray analysis (see Materials and Methods for details).

Table 1 lists some of the genes that were strongly regulated by FKHR in HUVECs (see Supplementary Tables S1-S4 for a complete list of FKHR-regulated genes). In addition to observing gene changes that are consistent with previously described functions of FKHR in other cell types (induction of apoptosis and cell cycle arrest), we observed regulation of genes that are known to have important vascular functions. For example, the expression of Flt-1, a VEGF receptor involved in angiogenesis (Luttun et al. 2002), was dramatically increased in response to FKHR. In addition, FKHR strongly induced the expression of Ang-2, an antagonist of Ang-1 signaling that is highly expressed at sites of vascular remodeling in vivo (Maisonpierre et al. 1997; Goede et al. 1998; Stratmann et al. 1998; Holash et al. 1999a; Zagzag et al. 1999; Zhang et al. 2003). Ang-2, by binding but not activating Tie2, is thought to block a stabilizing signal provided by Ang-1, thereby contributing to vessel instability and remodeling (Maisonpierre et al. 1997; Holash et al. 1999b). This hypothesis has recently been confirmed by analysis of Ang-2 null mice, in which postnatal vascular remodeling in the eye is defective (Gale et al. 2002).

Furthermore, we found that many of the genes most dramatically regulated by FKHR are known to be involved in either remodeling of the extracellular matrix or in cell migration (Table 1). Importantly, several of these genes have previously been implicated in vascular biol- ogy. For example, decorin, lumican, collagen type 3 , and fibulin-5 (also known as DANCE) are matrix proteins that are expressed preferentially in remodeling blood vessels as compared with stable vessels (Nakamura et al. 1999; St Croix et al. 2000; Nelimarkka et al. 2001). Semaphorin $3 \mathrm{C}$, anosmin, reelin, and slit2 are secreted proteins that have been studied most closely in the nervous system, as regulators of axon guidance/neuronal migration (Castellani and Rougon 2002; Hu et al. 2003; Tissir and Goffinet 2003). Recent data, however, indicate that class 3 semaphorins also play a role in endothelial cell adhesion and migration (Serini et al. 2003) and that slit2 promotes endothelial cell migration and tube formation (Wang et al. 2003).

Among the transcription factors regulated by FKHR were KLF5 and Id2 (Table 1). KLF5 is expressed in activated endothelial cells (as well as vascular smooth muscle cells) and appears to be required for tumor-induced angiogenesis (Shindo et al. 2002). Id2 is a member of a family of inhibitory transcription factors that includes Id1 and Id3, which have been shown to be required for blood vessel invasion into tumors (Lyden et al. 1999). Taken together, our data suggest a novel function for FKHR in regulating a program of gene expression that may serve to promote blood vessel destabilization and remodeling. Ang-1, by inhibiting this program, would thereby promote vessel stability.

As shown in Figure 2, FKHR induces apoptosis in endothelial cells. Consistent with this result, FKHR significantly induced the expression of TRAIL (TNF-related apoptosis-inducing ligand) and Bcl-6 (a transcriptional repressor; Table 1). Both of these genes have previously been implicated in FKHR-dependent apoptosis in other cell types (Modur et al. 2002; Tang et al. 2002), and may contribute to FKHR-mediated killing in endothelial cells. In fact, TRAIL has recently been shown to promote apoptosis in HUVECs (Li et al. 2003). In addition, FKHR significantly repressed the expression of survivin, which has been shown to inhibit endothelial cell apoptosis (O'Connor et al. 2000). Interestingly, survivin expression has previously been shown to be induced by Ang-1 (Papapetropoulos et al. 2000). Our data suggest the possibility that Ang-1 increases survivin expression by relieving the repressive effect of FKHR.

The largest class of genes repressed by FKHR comprises genes involved in cell cycle control, for example, cyclin D1 (Table 1). These data are consistent with the observation that FKHR induces cell cycle arrest in several cell types (Burgering and Medema 2003; Tran et al. 2003) and with recent microarray data indicating that FKHR represses D-type cyclins in renal carcinoma cells (Ramaswamy et al. 2002). Although repression of gene expression by FKHR appears to be independent of its ability to bind DNA (Ramaswamy et al. 2002), the exact mechanisms involved remain to be elucidated.

A direct comparison of the genes regulated by FKHR in endothelial cells to those regulated by FKHR in HeLa cells (our unpublished data), as well as in renal carcinoma cells (Ramaswamy et al. 2002) and prostate cancer cells (Modur et al. 2002), reveals that FKHR modulates 
Daly et al.

Table 1. Genes regulated by FKHR in endothelial cells

\begin{tabular}{|c|c|c|c|c|c|}
\hline \multirow[b]{2}{*}{ GenBank \# } & \multirow[b]{2}{*}{ Genes induced by FKHR } & \multicolumn{3}{|c|}{ Ratio FKHR/GFP } & \multirow[b]{2}{*}{ Functional class } \\
\hline & & $12 \mathrm{~h}$ & $16 \mathrm{~h}$ & $24 \mathrm{~h}$ & \\
\hline BC005322 & decorin & 39.99 & 35.92 & 100.00 & Matrix remodeling \\
\hline NM_002423 & matrix metalloproteinase 7 (matrilysin) & 37.84 & 100.00 & 100.00 & Matrix remodeling \\
\hline AF020761 & ubiquitin-conjugating enzyme E2D 1 & 8.31 & 13.28 & 9.28 & Intracellular signaling \\
\hline NM_024501 & homeo box D1 & 7.74 & 5.32 & 4.92 & Transcription \\
\hline U40372 & phosphodiesterase $1 C$ & 6.93 & 5.81 & 16.11 & Intracellular signaling \\
\hline АВ009865 & angiopoietin 2 & 6.89 & 17.01 & 14.33 & Angiogenesis \\
\hline AI679737 & EGF receptor pathway substrate 8 (eps8) & 6.55 & 4.99 & 4.76 & Intracellular signaling \\
\hline AF287272 & Kruppel-like factor 5 (KLF5) & 6.55 & 13.14 & 14.20 & Transcription \\
\hline AI299309 & Inhibitor of DNA binding 2 (Id2) & 6.33 & 8.78 & 13.48 & Transcription \\
\hline AW022060 & TNF superfamily, member 10 (TRAIL) & 6.13 & 3.72 & 2.76 & Signaling/apoptosis \\
\hline BG938585 & semaphorin $3 C$ & 5.88 & 8.65 & 86.63 & Axon guidance/angiogenesis \\
\hline AB053450 & Fibrillin 3 & 4.48 & 6.31 & 5.32 & Matrix remodeling \\
\hline AU137979 & Lumican & 3.14 & 7.69 & 26.83 & Matrix remodeling \\
\hline M69225 & Bullous pemphigold antigen 1 (230/240kD) & 2.54 & 7.27 & 11.97 & Matrix remodeling \\
\hline D45917 & TIMP-3 & 1.94 & 3.46 & 6.35 & Matrix remodeling \\
\hline AL570066 & Fibulin 5 (DANCE; EVEC) & 1.82 & 3.92 & 11.15 & Matrix remodeling \\
\hline X14420 & Pro- $\alpha-1$ type 3 collagen & 1.77 & 2.85 & 12.79 & Matrix remodeling \\
\hline M97252 & Kallmann syndrome 1 sequence (Anosmin) & 2.79 & 6.85 & 54.27 & Matrix remodeling \\
\hline AW263423 & Slit2 & 2.60 & 3.55 & 5.77 & Axon guidance/angiogenesis \\
\hline U00115 & B-cell CLL/lymphoma 6 (BCL-6) & 2.58 & 5.80 & 6.41 & Transcription/apoptosis \\
\hline NM_006080 & Semaphorin III (sema 3A) & & 8.16 & 10.52 & Axon guidance/angiogenesis \\
\hline NM_002019 & Fms related tyrosine kinase (Fit-1) & & 6.88 & 11.30 & Angiogenesis \\
\hline U79716 & Reelin & & 5.18 & 15.07 & Cell migration \\
\hline & Genes repressed by FKHR & & & & \\
\hline BF183143 & Serine/threonine kinase 12 & 1.23 & 0.50 & 0.18 & Cell cycle \\
\hline BI091762 & RAB6 interacting, kinesin-like (rabkinesin 6) & 1.14 & 0.44 & 0.15 & Cell cycle \\
\hline AL571008 & Survivin & 1.06 & 0.52 & 0.19 & Apoptosis/cell cycle \\
\hline BC006510 & Similar to cyclin B1 & 0.99 & 0.54 & 0.20 & Cell cycle \\
\hline NM_007317 & Kinesin-like 4 & 0.89 & 0.38 & 0.19 & Cell cycle \\
\hline U73379 & Cyclin-selective ubiquitin carrier protein & 0.84 & 0.35 & 0.17 & Cell cycle \\
\hline U66838 & Cyclin A1 & 0.69 & 0.44 & 0.20 & Cell cycle \\
\hline BG491883 & MCM2 & 0.48 & 0.22 & 0.17 & Cell cycle \\
\hline X59798 & Cyclin D1 & 0.16 & 0.12 & 0.31 & Cell cycle \\
\hline NM_004428 & Ephrin-A1 & & 0.32 & 0.19 & Signaling \\
\hline BC009426 & $C D C 20$ & & 0.31 & 0.14 & Cell cycle \\
\hline AL560982 & Centromere protein $A(17 k D)$ & & 0.29 & 0.17 & Cell cycle \\
\hline NM_002060 & Connexin 37 & & 0.13 & 0.09 & Signaling \\
\hline NM_005266 & Connexin 40 & & 0.19 & 0.10 & Signaling \\
\hline NM_005524 & Hairy Drosophila homolog (HES1) & & 0.11 & 0.09 & Transcription \\
\hline
\end{tabular}

HUVEC's were infected with adenoviruses encoding either GFP or FKHR-TM for 12, 16, or $24 \mathrm{~h}$. Total RNA was isolated and subjected to microarray analysis. The table lists a subset of the genes whose RNA level changed by more than fivefold in FKHR-expressing cultures relative to GFP-expressing cultures. For a complete list of FKHR-regulated genes, see Supplementary Tables S1-S4.

distinct, but overlapping sets of genes in different cell types. Many genes, for example, Ang-2, are induced by FKHR in an endothelial cell-specific manner (our unpublished data), supporting the contention that FKHR plays an important and unique role in blood vessels.

To validate our microarray data, Northern blot analysis was performed on RNA from HUVECs expressing GFP, FKHR-DB, or FKHR-TM. As shown in Figure 3A, Ang-2, MMP7, and semaphorin 3C RNAs were induced specifically in FKHR-TM-expressing cells, whereas survivin was repressed. In addition, the induction of Id2, slit2, and decorin RNAs by FKHR was confirmed by realtime PCR analysis (data not shown). We also verified by
Western blot the FKHR-mediated induction of Ang-2, Id2, and grancalcin and the repression of survivin (Fig. 3B). Importantly, the transcriptional response to FKHRTM is not unique to HUVECs, but is shared by other endothelial cell types. For example, FKHR can induce Ang-2, Id2, and decorin expression in MVECs (see Fig. 4).

To confirm that regulation of gene expression by FKHR-TM is dependent on its ability to bind DNA, we used a version of FKHR-TM in which a conserved histidine in helix 3 of the forkhead domain was changed to arginine (FKHR-TM H212R). This histidine is essential for FKHR binding to its consensus DNA element $\left(5^{\prime}\right.$ TTGTTTAC; Tang et al. 1999). HUVECs were infected 


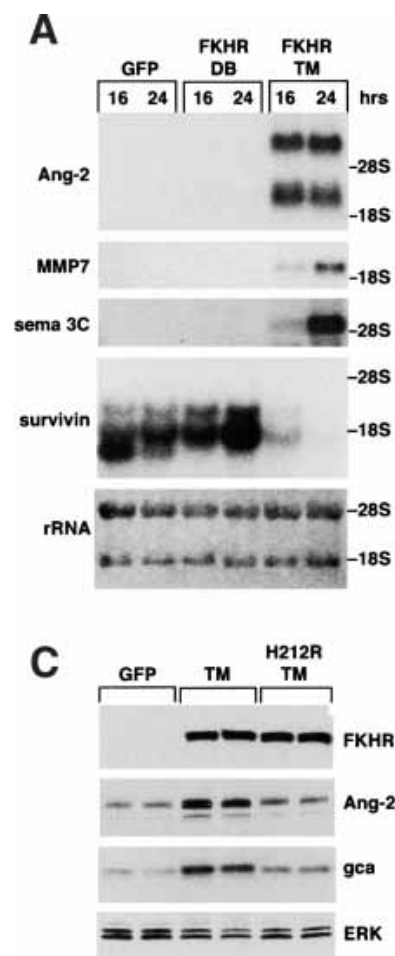

Figure 3. Validation of microarray data. $(A)$ HUVECs were infected with adenoviruses encoding GFP, FKHR-DB, or FKHRTM for 16 or $24 \mathrm{~h}$. Total RNA was isolated and subjected to Northern blot using probes specific for Ang-2, MMP7, semaphorin $3 \mathrm{C}$, or survivin. Ethidium bromide-stained rRNA is shown to confirm equal loading. ( $B, t o p$ panel) HUVECs were infected with adenoviruses encoding either GFP or FKHR-TM for 8,12 , or $24 \mathrm{~h}$. Cell lysates were prepared and subjected to Western blot with antibodies against Ang-2, Id2, myc tag (detects FKHR-TM), GFP, or ERK. (Bottom panel) HUVECs were infected with adenoviruses encoding either GFP or FKHR-TM for 16, 20, or $24 \mathrm{~h}$. Cell lysates were prepared and subjected to Western blot with antibodies against survivin, grancalcin, or myc tag (FKHR-TM). (C) HUVECs were infected with viruses encoding either GFP, FKHR-TM, or FKHR-TM H212R for $24 \mathrm{~h}$. Cell lysates were prepared and subjected to Western blot with antibodies against myc tag (FKHR), Ang-2, grancalcin (gca), and ERK. Each infection was done in triplicate, with similar results (two samples from each set are shown).

with viruses encoding GFP, FKHR-TM, or FKHR-TM H212R. After $24 \mathrm{~h}$, cell lysates were prepared and subjected to immunoblot with antibodies against myc tag (detects FKHR variants), Ang-2, and grancalcin. As shown in Figure 3C, despite the fact that FKHR-TM and FKHR-TM H212R were expressed at equal levels, FKHR-TM H212R failed to induce expression of Ang-2 and grancalcin. Thus, induction of these genes requires association of FKHR with its consensus DNA-binding site.

To test whether Ang-1 can inhibit FKHR-mediated gene expression, MVECs were infected with viruses encoding either GFP or FKHR (with the Akt sites intact). As shown in Figure 4, expression of FKHR resulted in an increase in the levels of Ang-2, decorin, and Id2 RNAs, as measured by real-time PCR, and this induction was significantly inhibited by treatment with Ang-1, confirming that Ang-1 blocks FKHR-dependent changes in gene expression.

To provide evidence that the endogenous FKHR protein contributes to the regulation of the genes that we identified by microarray (Table 1), and to confirm that FKHR is a major target through which Akt regulates transcription in endothelial cells, we inhibited endogenous FKHR activity by expressing myrAkt. As shown in Figure $5 \mathrm{~A}$, myrAkt is highly phosphorylated relative to the endogenous Akt, resulting in a robust increase in phosphorylation (inhibition) of FKHR. If the basal level of FKHR activity in unstressed cells modulates expression of a gene (because, e.g., the promoter is responsive to relatively low levels of FKHR activity), then myrAkt should modulate expression of that gene in the opposite direction. Although many of the genes which were induced in response to activated FKHR are expressed at very low levels in quiescent HUVECs (as assessed by real-time PCR or Northern blot), making it difficult to detect a decrease in their expression, it seemed likely that the basal expression of a subset of the FKHR-responsive genes would be regulated by Akt. To investigate the regulation of gene expression by Akt in endothelial cells,

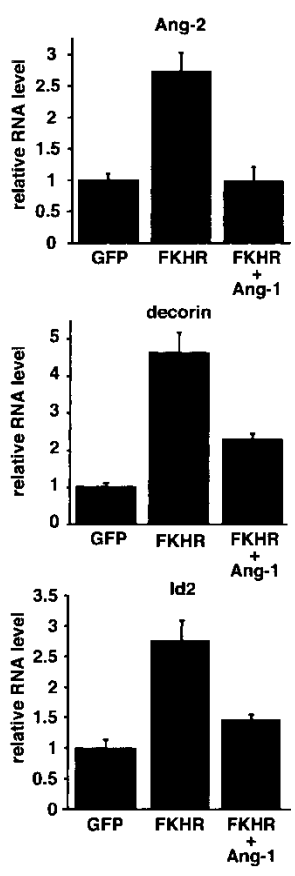

Figure 4. Angiopoietin-1 inhibits FKHR-mediated changes in gene expression. MVECs were infected with adenoviruses encoding either GFP or FKHR. At $9 \mathrm{~h}$ after infection, FKHR-expressing cultures were either untreated or stimulated with Ang1. At $14 \mathrm{~h}$ after infection, total RNA was isolated and the relative levels of Ang-2, decorin, and Id2 RNAs (normalized to GAPDH) were determined by real-time PCR. The data are expressed as relative RNA level versus GFP control (assigned a value of 1.0). Bars represent the mean and S.D., $n=3$. The effect of Ang-1 on the levels of Ang-2, decorin, and Id2 RNAs was statistically significant by $t$-test, $p<0.005$. 
Daly et al.

Figure 5. Regulation of gene expression by the endogenous FKHR protein. (A) HUVECs were infected with adenoviruses encoding either GFP or myrAkt (the samples in lanes 1,2 and 3,4 are duplicates) for $24 \mathrm{~h}$. Cell lysates were prepared and subjected to Western blot with antibodies against phospho-Akt (Ser 473), Akt, phospho-FKHR (Thr $24)$, or FKHR. The myrAkt protein is larger than the endogenous Akt because it is tagged with eGFP. (B) HUVECs were infected with adenoviruses encoding either GFP or myrAkt for 16 or 24 h. Total RNA was isolated and the relative levels (normalized to actin) of Ang-2, CTGF, and ESM-1 RNAs were determined by real-time PCR. For each RNA analyzed, the level in the GFP-expressing cells was assigned a value of 1.0. $(C)$ HUVECs were infected with adenoviruses encoding either a negative control siRNA or siRNA against FKHR. At 48 and $72 \mathrm{~h}$ after infection, cell lysates were prepared and subjected to Western blot with antibodies against FKHR, Ang-2, Akt, and ERK. (Right) The relative levels of FKHR and Ang-2 proteins (assigned a value of 1.0 in the control samples) were quantitated and plotted. The bars represent the mean and S.D., $n=3$. The effect of the FKHR siRNA on FKHR and Ang- 2 protein levels was statistically significant at both time points by $t$-test, $p<0.001$. (D) HUVECs were infected with adenoviruses encoding either a negative control siRNA or siRNA against FKHR. At $48 \mathrm{~h}$ after infection, total RNA was isolated and the relative levels (normalized to cyclophilin) of FKHR, Ang-2, ESM-1, and CTGF RNAs were determined by real-time PCR. Bars represent the mean and S.D., $n=4$. The effect of FKHR siRNA on the levels of each RNA was statistically significant by $t$-test, $p<0.0001$.
A
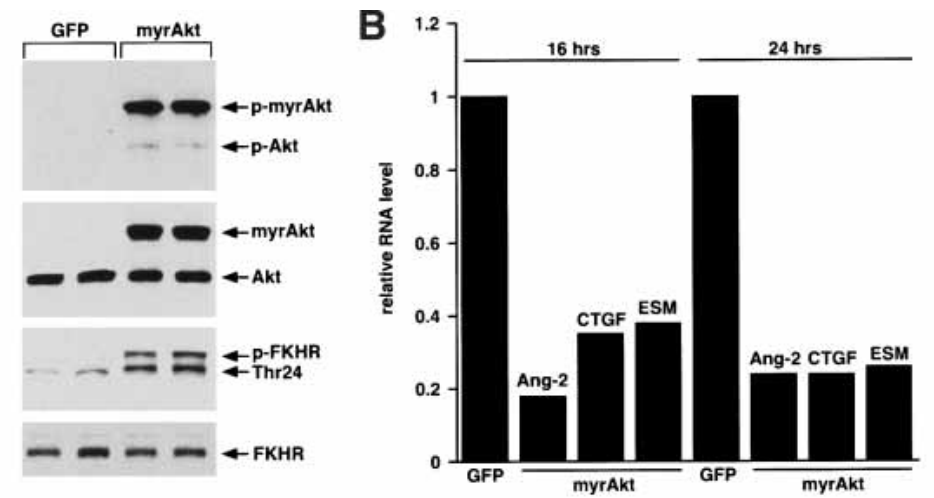

C
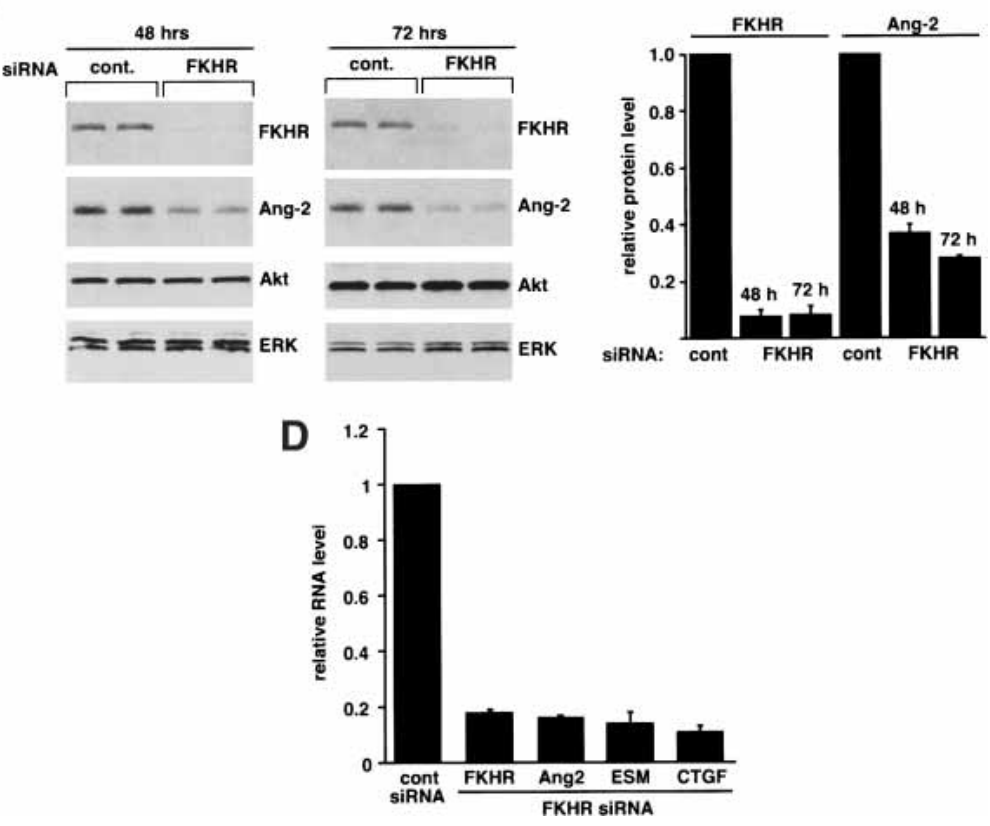

HUVECs were infected with viruses encoding either GFP or myrAkt for 16, 20, or $24 \mathrm{~h}$, and RNA was isolated and subjected to microarray analysis. Table 2 lists genes that were either induced more than fivefold or repressed more than threefold by Akt and that we had previously shown to be significantly regulated by FKHR in the opposite direction (a complete description of the Akt microarray results will be published elsewhere). Importantly, a significant fraction of the genes that were most dramatically regulated by Akt were also FKHR target genes. For example, among the 10 genes most strongly repressed by Akt were four genes that are induced by FKHR (FABP4, EGR1, CLEC2, and Ang-2; Table 2). These data confirm that FKHR is a major target in Aktdependent regulation of gene expression.

Several of the Akt-repressed genes (in addition to Ang2) are known to have important vascular functions. For example, CTGF is a growth factor that promotes endothelial cell proliferation and migration and that is expressed (induced by VEGF) in settings of vessel remodeling/angiogenesis (Brigstock 2002). ESM-1 is a cell surface integrin-binding protein whose expression is induced in endothelial cells undergoing tube formation
(Aitkenhead et al. 2002). EDG6 is a G-protein-coupled receptor for sphingosine-1-phosphate, a potent stimulator of endothelial cell migration (Ozaki et al. 2003).

To validate our microarray data, RNA isolated from HUVECs expressing GFP or myrAkt was subjected to real-time PCR analysis. As shown in Figure 5B, myrAkt significantly repressed the Ang-2, CTGF, and ESM-1 RNAs at both 16 and $24 \mathrm{~h}$ after infection. In addition, Ang-1 treatment of endothelial cells resulted in a decrease in Ang-2 expression, presumably via activation of Akt (Supplementary Fig. S2). These results suggest that endogenous FKHR activity contributes to the basal expression of these genes. To directly confirm this, we used RNA interference to decrease FKHR protein levels in HUVECs. Because primary endothelial cells are difficult to transfect, we chose to use adenovirus to deliver the small interfering RNA (siRNA), which was synthesized as a hairpin from an RNA polymerase III promoter (Paddison et al. 2002). HUVECs were infected for 48 or $72 \mathrm{~h}$ with adenoviruses encoding either siRNA against FKHR or a negative control siRNA. As shown in Figure 5C, expression of siRNA against FKHR resulted in a dramatic $(-90 \%)$ decrease in FKHR protein levels at both 
Table 2. Reciprocal regulation of endothelial cell gene expression by Akt and FKHR

\begin{tabular}{|c|c|c|c|}
\hline GenBank \# & Gene name & $\begin{array}{l}\text { Max fold change } \\
\text { myrAkt/GFP }\end{array}$ & $\begin{array}{l}\text { Max fold change } \\
\text { FKHR/GFP }\end{array}$ \\
\hline ВТ006809 & Fatty acid binding protein 4 (FABP4) & 0.1 & 7.09 \\
\hline NM_001964 & Early growth response 1 (EGR1) & 0.12 & 7.12 \\
\hline X96719 & C-type lectin superfamily member 2 (CLEC2) & 0.16 & 8.06 \\
\hline NM_001147 & Angiopoietin 2 (Ang-2) & 0.18 & 17.01 \\
\hline NM_001901 & Connective tissue growth factor (CTGF) & 0.21 & 3.12 \\
\hline NM_007036 & Endothelial cell-specific molecule 1 (ESM-1) & 0.25 & 10.52 \\
\hline NM_080760 & Dachshund homolog (Drosophila) & 0.25 & 3.58 \\
\hline NM_021229 & Protein with strong similarity to netrin 4 & 0.27 & 3.71 \\
\hline X07820 & Matrix metalloproteinase 10 (MMP 10) & 0.27 & 3.93 \\
\hline NM_003775 & $E D G 8$ & 0.32 & 3.48 \\
\hline NM_002962 & Cytokine A2 & 13.07 & 0.11 \\
\hline NM_005630 & Solute carrier family 21 & 8.65 & 0.26 \\
\hline NM_030817 & Protein of unknown function & 7.46 & 0.28 \\
\hline NM_006988 & ADAMTS1 & 7.44 & 0.44 \\
\hline NM_139314 & Angiopoietin-like 4 & 6.16 & 0.13 \\
\hline NM_198337 & Insulin induced gene 1 & 5.91 & 0.22 \\
\hline NM_019058 & HIF-1 responsive RTP801 & 5.91 & 0.14 \\
\hline NM_004609 & Transcription factor 15 & 5.06 & 0.09 \\
\hline
\end{tabular}

HUVECs were infected with adenoviruses encoding either GFP or myrAkt for 16, 20, or $24 \mathrm{~h}$. RNA was isolated and subjected to microarray analysis. Genes whose expression was either induced greater than fivefold or repressed greater than threefold by Akt and that we had previously shown to be regulated in the opposite direction by FKHR are listed. The number reported for the myrAkt/GFP ratio indicates the maximum fold change for that gene during the time course of the experiment $(16,20$, or $24 \mathrm{~h})$.

time points, as compared with cells expressing a control siRNA. Importantly, the decrease in the level of FKHR protein was accompanied by a significant decrease in the level of Ang-2 protein (to $\sim 40 \%$ of control levels at $48 \mathrm{~h}$ and to $\sim 30 \%$ at $72 \mathrm{~h}$ ), confirming that FKHR is required for Ang-2 expression (Fig. 5C). The decrease in FKHR protein did not have a global effect on the level of other proteins, as shown by immunoblot against Akt and ERK (Fig. 5C). Furthermore, siRNA-mediated reduction in the level of FKHR resulted in a significant reduction in the levels of Ang-2, ESM-1, and CTGF RNAs (Fig. 5D), while

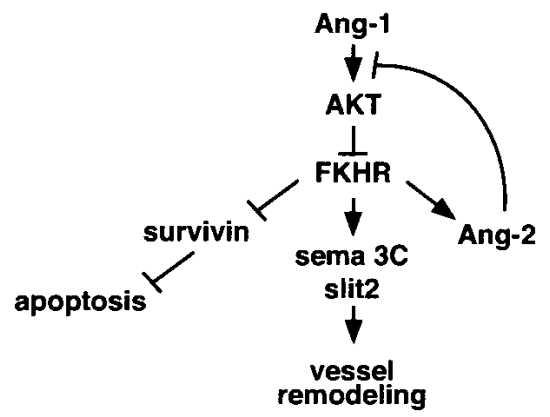

Figure 6. Angiopoietin-1 regulates endothelial cell gene expression via FKHR. Ang-1, via activation of the Akt pathway, inhibits FKHR-dependent changes in the expression of genes that regulate vascular remodeling and endothelial cell apoptosis. The induction of Ang-2 expression by FKHR (or by other signals) might initiate a positive feedback loop in which Ang-2, by blocking Ang-1/Akt signaling, induces further increases in its own expression and in the expression of genes like semaphorin 3C and slit2, which may directly promote vessel destabilization and remodeling. having no effect on the levels of the control RNAs cyclophilin and TATA-box-binding protein (TBP; data not shown). These data confirm that Ang-2, ESM-1, and CTGF are downstream targets of the endogenous FKHR transcription factor.

\section{Discussion}

Previous studies have suggested that Ang-1 is a regulator of vascular maturation and stability (Sato et al. 1995; Davis et al. 1996; Suri et al. 1996), as well as an endothelial cell survival factor (Kim et al. 2000; Papapetropoulos et al. 2000; Jones et al. 2001). However, the pathways through which Ang-1 regulates gene expression, and the nature of the responsive genes themselves, have remained unknown. In this report, we have demonstrated that Ang-1 inhibits FKHR function in endothelial cells and that FKHR modulates the expression of genes associated with blood vessel destabilization/remodeling and apoptosis (Fig. 6). Notably, FKHR regulates the expression of genes, like Ang-2, that have specific and essential roles in the vasculature, suggesting that inhibition of FKHR is an important mechanism through which Ang-1 modulates endothelial cell function. Recently published data showing that FKHR null embryos exhibit dramatic defects in vascular development (Hosaka et al. 2004) supports the idea that the Ang-1/Akt/FKHR pathway is an important regulator of blood vessel function.

A role for Ang-1 in promoting vascular maturation and stability was initially suggested by analysis of Ang-1 null embryos, in which endothelial cells do not maintain their normally tight association with surrounding support cells and extracellular matrix (Suri et al. 1996). In 
contrast, the Ang-1-antagonist Ang-2, which binds but does not activate Tie2, is associated with blood vessel destabilization and remodeling (Maisonpierre et al. 1997). Expression of Ang-2 is markedly increased in the endothelial cells of remodeling vessels, for example, in tumors (Stratmann et al. 1998; Holash et al. 1999a; Zagzag et al. 1999; Zhang et al. 2003) and in the ovary (Maisonpierre et al. 1997; Goede et al. 1998), and Ang-2 has recently been shown to be required for postnatal vascular remodeling in the eye (Gale et al. 2002). Presumably, the effect of Ang-2 is due to its ability to block a stabilizing signal provided by Ang-1, although the nature of the stabilizing signal has remained unclear. Our data indicate that FKHR, in addition to inducing expression of Ang-2, also increases the expression of several genes that may contribute directly to vessel destabilization. As discussed earlier, such genes include several that have been implicated in matrix remodeling in the vasculature (decorin, lumican, fibulin-5, and type 3 collagen; Nakamura et al. 1999; St Croix et al. 2000; Nelimarkka et al. 2001) or in endothelial cell migration and tube formation (semaphorin, slit2; Serini et al. 2003; Wang et al. 2003). Thus, our data suggest that FKHR activation in blood vessels is likely to be coupled to changes in the interaction between endothelial cells and the surrounding support cells and matrix. Inhibition of FKHR function by Ang-1 may, therefore, explain, at least partly, the effects of Ang-1 on vessel stability.

Two recent studies have shown that forced overexpression of Ang-1 in tumor cells has an inhibitory effect on tumor growth following implantation of the cells into mice (Hawighorst et al. 2002; Stoeltzing et al. 2003). In a study of squamous cell carcinoma xenografts, Ang-1 promoted coverage of tumor vessels with pericytes, (suggesting a positive effect of Ang-1 on vessel maturation) and inhibited tumor growth, possibly by blocking sprouting angiogenesis (Hawighorst et al. 2002). Furthermore, Ang-1 has been shown to inhibit angiogenesis induced by transgenic expression of either VEGF or VEGF/ Ang-2 in the heart (Visconti et al. 2002). It would be interesting to determine whether the effect of Ang-1 in these models is the result of inhibition of FKHR action.

Interestingly, our data have established that Ang-1 inhibits, via the FKHR pathway, the expression of its antagonist Ang-2 (Fig. 4). This regulation implies the existence of a positive feedback loop in which an increase in Ang-2 expression (whether induced by FKHR or another factor) leads to activation of FKHR (via inhibition of Ang-1 signaling), resulting in a further increase in the expression of Ang-2 and of other FKHR target genes (Fig. 6). This suggests the possibility that relatively small changes in Ang-2 levels could ultimately have dramatic effects on blood vessel stability.

Our microarray analysis indicates that FKHR also regulates the expression of genes that have previously been implicated in the control of endothelial cell apoptosis, for example, survivin and TRAIL /O'Connor et al. 2000; Li et al. 2003), suggesting that the prosurvival effects of Ang-1 are due to inhibition of FKHR action. One could imagine that during vessel remodeling, Ang-2-me- diated inhibition of Ang-1/Akt signaling would lead to activation of FKHR, making vessels unstable and susceptible to apoptosis. As proposed previously (Maisonpierre et al. 1997; Holash et al. 1999b), a destabilized vessel would be prone to two fates: in the presence of VEGF, endothelial cells would survive and angiogenesis would proceed; in the absence of VEGF, endothelial cells would undergo apoptosis, leading to vessel regression. Genetic manipulation of components of the Ang-1/Akt/FKHR pathway in vivo and in an endothelial cell-specific manner will be required to fully understand how this signaling cascade regulates vascular function.

\section{Materials and methods}

\section{Cell culture and recombinant proteins}

Human umbilical vein endothelial cells (HUVECs) and bovine lung microvascular endothelial cells (MVECs) were obtained from Vec Technologies. Cells were routinely cultured in MCDB131 complete medium. Cells were treated with the following growth factors: Ang- 1 at $1 \mu \mathrm{g} / \mathrm{mL}$, human VEGF $_{165}$ at 50 $\mathrm{ng} / \mathrm{mL}$, human bFGF (R\&D Systems) at $10 \mathrm{ng} / \mathrm{mL}$. The design and production of the Ang-1 protein used in this study (Ang- $\mathrm{F}_{1}$ $\mathrm{Fc}_{\mathrm{C}} \mathrm{F}_{1}$ ) has been described recently (Davis et al. 2003). Briefly, Ang- $F_{1}-F_{c}-F_{1}$ consists of two Ang-1 fibrinogen-like domains separated by the Fc domain of human IgG1. Owing to Fc-mediated dimerization, the Ang-1 fibrinogen-like domains are presented to Tie2 in tetrameric form, a requirement for efficient activation of Tie2 in endothelial cells. Ang- $\mathrm{F}_{1}-\mathrm{Fc}-\mathrm{F}_{1}$ binds to and activates Tie2 similarly to native Ang-1 (Davis et al. 2003).

\section{Antibodies}

The following antibodies were used for Western blots: phosphoAkt (Ser 473), Akt, phospho-p44/42 MAP kinase (Thr 202/Tyr 204), p44/42 MAP kinase, phospho-FKHR (Ser 256), and cleaved caspase-3 (Asp175) antibodies (Cell Signaling Technology). FKHR (H-128), c-myc (9E10), Id2 (C-20), survivin (FL-142), and grancalcin (N-20) antibodies were from Santa Cruz Biotechnology. Anti-GFP antibody was from Clontech. CREB and phospho-FKHRL1 (Thr 32; this antibody recognizes phosphoThr 24 in FKHR) antibodies were from Upstate Biotechnology. GAPDH antibody was from Chemicon. The Ang-2 antibody is a purified rabbit polyclonal raised against amino acids 3-22 of the human Ang- 2 protein. Primary antibodies were used in immunoblotting and immunofluorescence at the dilutions recommended by the manufacturers.

\section{Plasmids}

A full-length cDNA encoding FKHR was a gift of D. Accili (Columbia University, New York) and was subsequently cloned into the mammalian expression vector pcDNA3.1/Myc-His ${ }^{-}$. The FKHR protein encoded by this plasmid has a myc tag at its C terminus. The Akt sites in FKHR were mutated (Thr 24, Ser 253 , and Thr 316 were all changed to alanine) to generate FKHRTM. Histidine 212 in FKHR-TM was changed to arginine to generate FKHR-TM H212R. All point mutants were constructed using the QuikChange XL Site Directed Mutagenesis Kit (Stratagene). The FKHR-DB plasmid encodes amino acids 140276 of FKHR (which is essentially just the DNA-binding domain). The protein encoded by pcDNA3.1-myrAkt contains the 10-amino-acid myristoylation signal from c-src at its $\mathrm{N}$ termi- 
nus. The luciferase reporter construct containing the FOXObinding sites from the Fas ligand promoter (FHRE-luc) was a gift of M. Greenberg and has been described previously (Brunet et al. 1999).

\section{Cell fractionation}

To prepare cytoplasmic and nuclear fractions, cells were scraped into hypotonic lysis buffer $(10 \mathrm{mM} \mathrm{NaCl}, 20 \mathrm{mM}$ HEPES at $\mathrm{pH}$ $7.4,3 \mathrm{mM} \mathrm{MgCl} 2,0.05 \% \mathrm{NP}-40$ ) and incubated on ice for $2 \mathrm{~min}$. Nuclei were then pelleted at $2000 \mathrm{~g}$ in a microfuge, and the supernatant (cytoplasmic fraction) was collected. The nuclear pellet was resuspended in SDS sample buffer, and the fractions were subjected to Western blot analysis.

\section{Transfections and luciferase assay}

MVECs were transfected using Lipofectin reagent (Life Technologies). The day before transfection, $1.5 \times 10^{5}$ cells were seeded in 6-well plates. Transfections were routinely done using a total of $2 \mu \mathrm{g}$ of plasmid DNA and $10 \mu \mathrm{L}$ of Lipofectin reagent for $4 \mathrm{~h}$ in Opti-MEM reduced serum medium (Life Technologies). Expression plasmids encoding eGFP, FKHR, FKHR-TM, and myrAkt were used at 50-100 ng/well. The FHRE-luc reporter plasmid was used at $0.5 \mu \mathrm{g} /$ well. After $4 \mathrm{~h}$ of transfection, cells were washed with MCDB131 complete medium and fed with MCDB131. Lysates were routinely prepared at $24 \mathrm{~h}$ after transfection, and luciferase assays were performed using the Luciferase Assay System from Promega according to manufacturer's instructions.

\section{Adenovirus construction and viral infections}

Recombinant E1, E3-deleted adenovirus vectors were constructed using the Ad Max Cre-lox-based system (Microbix Biosystems Inc.). To generate adenoviruses encoding FKHR, FKHRTM, FKHR-TM H212R, FKHR-DB, and myrAkt, the cDNAs described above were moved from pcDNA3.1/Myc-His ${ }^{-}$into the pDC315 shuttle vector. Infectious virus was purified and titered using standard techniques. For viral infection, cells were washed with Opti-MEM reduced serum medium, and then incubated with the appropriate viruses in Opti-MEM for $4 \mathrm{~h}$. The virus-containing medium was then removed, and cultures were washed and fed with MCDB131 medium. HUVECs were generally infected at an m.o.i. of $\sim 15$, whereas MVECs were infected at an m.o.i. of 50-100.

\section{Apoptosis assays}

Cell cultures were assessed for apoptosis following expression of FKHR or FKHR-TM by Western blotting with antibody against the active form of caspase-3, by staining with Hoechst 33342 (Molecular Probes) and by MTS assay. For Hoechst staining, cells grown on coverslips were fixed with methanol, stained with Hoechst at $1.5 \mu \mathrm{g} / \mathrm{mL}$ in PBS for $15 \mathrm{~min}$, and then washed with PBS. MTS assay, which determines the number of viable cells in a culture, was performed with the CellTiter 96 Aqueous One Solution Cell Proliferation Assay kit from Promega according to the manufacturer's instructions.

\section{Microarray analysis}

Total RNA was isolated from cells using TriReagent (Molecular Research Center) and used to prepare Cyanine 3- or Cyanine 5-labeled cDNA. Cyanine 3-labeled cDNA and Cyanine 5-labeled cDNA was mixed together and hybridized to either Ag- ilent human 1 cDNA microarray (catalog no. G4100A; contains 12,814 unique cDNAs/array) or to Agilent human oligo microarray (catalog no. G4110A; contains 22,000 unique 60-nt oligonucleotides representing $>17,000$ human genes), as described previously (Wei et al. 2002). After washing, micorarrays were scanned using the Agilent microarray scanner, and data were extracted using Agilent's Feature Extraction software. For each comparison, dye swap was performed to eliminate the effect of dye bias. The final ratio (FKHR/GFP, i.e., fold change) is the average of the two individual ratios from the dye swap experiment.

\section{Northern blotting and Taqman real-time PCR}

RNA for Northern blotting and real-time PCR was isolated with TriReagent (Molecular Research Center). Northern blotting was done using standard techniques. For Taqman real-time PCR assays, cDNA was synthesized using Taqman Reverse Transcription Reagent kit (Applied Biosystems). For each RNA sample, a control reaction was run in which no reverse transcriptase was added, allowing for subsequent subtraction of any signal caused by genomic DNA contamination. PCR reactions contained 25 ng of cDNA, the gene specific primers at a final concentration of $0.9 \mu \mathrm{M}$ each and the Taqman probe at a final concentration of $0.2 \mu \mathrm{M}$. The assays were run under standard Taqman conditions on the ABI $7900 \mathrm{HT}$ instrument. The threshold cycle was determined and used to estimate the quantity of each RNA (based on a standard curve generated from known amounts of genomic DNA). The results were expressed as the ratio of the amount of the RNA of interest to the amount of a control RNA (actin or gapdh).

\section{RNA interference}

To generate adenoviruses expressing siRNAs as hairpins, the CMV promoter of the shuttle vector pDC316 was replaced with an expression cassette from the pSIREN-Shuttle vector (BD Biosciences Clontech; Knockout RNAi Systems) consisting of the human U6 promoter (an RNA polymerase III promoter) and a cloning site (BamHI/EcoRI). The resulting plasmid is called pDC316 SIREN. Synthetic oligonucleotides were designed according to the recommendations in the BD Knockout RNAi Systems User Manual, and cloned into the BamHI/EcoRI sites of pDC316 SIREN. The FKHR target sequence used was: 5'GAGCGTGCCCTACTTCAAGGA-3', corresponding to nucleotides 889-907 of the human FKHR cDNA. RNA interference targeting this sequence has recently been shown to be effective at reducing FKHR protein levels in HUVECs (Potente et al. 2003). An adenovirus encoding an siRNA against luciferase (the relevant oligonucleotide was supplied in the BD Knockout RNAi Systems kit) was used as a negative control.

\section{Acknowledgments}

We thank M. Greenberg and D. Accili for providing plasmids, F. Martin and I. Hidalgo for technical assistance, V. Lan for help with graphics, D. Glass for helpful discussions, and the Protein Sciences group at Regeneron for providing purified Ang-1 and VEGF.

The publication costs of this article were defrayed in part by payment of page charges. This article must therefore be hereby marked "advertisement" in accordance with 18 USC section 1734 solely to indicate this fact.

\section{References}

Abid, M.R., Guo, S., Minami, T., Spokes, K.C., Ueki, K., Skurk, C., Walsh, K., and Aird, W.C. 2004. Vascular endothelial 
growth factor activates PI3K/Akt/forkhead signaling in endothelial cells. Arterioscler. Thromb. Vasc. Biol. 24: 294300.

Aitkenhead, M., Wang, S.J., Nakatsu, M.N., Mestas, J., Heard, C., and Hughes, C.C. 2002. Identification of endothelial cell genes expressed in an in vitro model of angiogenesis: Induction of ESM-1, ßig-h3, and NrCAM. Microvasc. Res. 63: 159171.

Biggs III, W.H., Meisenhelder, J., Hunter, T., Cavenee, W.K., and Arden, K.C. 1999. Protein kinase B/Akt-mediated phosphorylation promotes nuclear exclusion of the winged helix transcription factor FKHR1. Proc. Nat1. Acad. Sci. 96: 74217426.

Brigstock, D.R. 2002. Regulation of angiogenesis and endothelial cell function by connective tissue growth factor (CTGF) and cysteine-rich 61 (CYR61). Angiogenesis 5: 153-165.

Brunet, A., Bonni, A., Zigmond, M.J., Lin, M.Z., Juo, P., Hu, L.S., Anderson, M.J., Arden, K.C., Blenis, J., and Greenberg, M.E. 1999. Akt promotes cell survival by phosphorylating and inhibiting a Forkhead transcription factor. Cell 96: 857-868.

Brunet, A., Kanai, F., Stehn, J., Xu, J., Sarbassova, D., Frangioni, J.V., Dalal, S.N., DeCaprio, J.A., Greenberg, M.E., and Yaffe, M.B. 2002. 14-3-3 transits to the nucleus and participates in dynamic nucleocytoplasmic transport. J. Cell Biol. 156: 817828.

Burgering, B.M. and Medema, R.H. 2003. Decisions on life and death: FOXO Forkhead transcription factors are in command when PKB/Akt is off duty. J. Leukoc. Biol. 73: 689-701.

Castellani, V. and Rougon, G. 2002. Control of semaphorin signaling. Curr. Opin. Neurobiol. 12: 532-541.

Davis, S., Aldrich, T.H., Jones, P.F., Acheson, A., Compton, D.L., Jain, V., Ryan, T.E., Bruno, J., Radziejewski, C., Maisonpierre, P.C., et al. 1996. Isolation of angiopoietin-1, a ligand for the TIE2 receptor, by secretion-trap expression cloning. Cell 87: 1161-1169.

Davis, S., Papadopoulos, N., Aldrich, T.H., Maisonpierre, P.C., Huang, T., Kovac, L., Xu, A., Leidich, R., Radziejewska, E., Rafique, A., et al. 2003. Angiopoietins have distinct modular domains essential for receptor binding, dimerization and superclustering. Nat. Struct. Biol. 10: 38-44.

Gale, N.W., Thurston, G., Hackett, S.F., Renard, R., Wang, Q., McClain, J., Martin, C., Witte, C., Witte, M.H., Jackson, D., et al. 2002. Angiopoietin-2 is required for postnatal angiogenesis and lymphatic patterning, and only the latter role is rescued by angiopoietin-1. Dev. Cell 3: 411-423.

Goede, V., Schmidt, T., Kimmina, S., Kozian, D., and Augustin, H.G. 1998. Analysis of blood vessel maturation processes during cyclic ovarian angiogenesis. Lab. Invest. 78: 13851394.

Hawighorst, T., Skobe, M., Streit, M., Hong, Y.K., Velasco, P., Brown, L.F., Riccardi, L., Lange-Asschenfeldt, B., and Detmar, M. 2002. Activation of the tie2 receptor by angiopoietin-1 enhances tumor vessel maturation and impairs squamous cell carcinoma growth. Am. J. Pathol. 160: 1381-1392.

Holash, J., Maisonpierre, P.C., Compton, D., Boland, P., Alexander, C.R., Zagzag, D., Yancopoulos, G.D., and Wiegand, S.J. 1999a. Vessel cooption, regression, and growth in tumors mediated by angiopoietins and VEGF. Science 284: 19941998.

Holash, J., Wiegand, S.J., and Yancopoulos, G.D. 1999b. New model of tumor angiogenesis: Dynamic balance between vessel regression and growth mediated by angiopoietins and VEGF. Oncogene 18: 5356-5362.

Hosaka, T., Biggs III, W.H., Tieu, D., Boyer, A.D., Varki, N.M., Cavenee, W.K., and Arden, K.C. 2004. Disruption of forkhead transcription factor (FOXO) family members in mice reveals their functional diversification. Proc. Natl. Acad. Sci. 101: 2975-2980.

Hu, Y., Tanriverdi, F., MacColl, G.S., and Bouloux, P.M. 2003. Kallmann's syndrome: Molecular pathogenesis. Int. J. Biochem. Cell Biol. 35: 1157-1162.

Jones, N., Voskas, D., Master, Z., Sarao, R., Jones, J., and Dumont, D.J. 2001. Rescue of the early vascular defects in Tek/ Tie2 null mice reveals an essential survival function. EMBO Rep. 2: 438-445.

Kim, I., Kim, H.G., So, J.N., Kim, J.H., Kwak, H.J., and Koh, G.Y. 2000. Angiopoietin-1 regulates endothelial cell survival through the phosphatidylinositol 3'-kinase/Akt signal transduction pathway. Circ. Res. 86: 24-29.

Kohn, A.D., Takeuchi, F., and Roth, R.A. 1996. Akt, a pleckstrin homology domain containing kinase, is activated primarily by phosphorylation. J. Biol. Chem. 271: 21920-21926.

Li, J.H., Kirkiles-Smith, N.C., McNiff, J.M., and Pober, J.S. 2003. TRAIL induces apoptosis and inflammatory gene expression in human endothelial cells. J. Immunol. 171: 1526-1533.

Luttun, A., Tjwa, M., and Carmeliet, P. 2002. Placental growth factor (PlGF) and its receptor Flt-1 (VEGFR-1): Novel therapeutic targets for angiogenic disorders. Ann. NY Acad. Sci. 979: 80-93.

Lyden, D., Young, A.Z., Zagzag, D., Yan, W., Gerald, W., O'Reilly, R., Bader, B.L., Hynes, R.O., Zhuang, Y., Manova, K., et al. 1999. Id1 and Id3 are required for neurogenesis, angiogenesis and vascularization of tumour xenografts. $\mathrm{Na}$ ture 401: 670-677.

Maisonpierre, P.C., Suri, C., Jones, P.F., Bartunkova, S., Wiegand, S.J., Radziejewski, C., Compton, D., McClain, J., Aldrich, T.H., Papadopoulos, N., et al. 1997. Angiopoietin-2, a natural antagonist for Tie2 that disrupts in vivo angiogenesis. Science 277: 55-60.

Modur, V., Nagarajan, R., Evers, B.M., and Milbrandt, J. 2002. FOXO proteins regulate tumor necrosis factor-related apoptosis inducing ligand expression. Implications for PTEN mutation in prostate cancer. J. Biol. Chem. 277: 4792847937.

Nakamura, T., Ruiz-Lozano, P., Lindner, V., Yabe, D., Taniwaki, M., Furukawa, Y., Kobuke, K., Tashiro, K., Lu, Z., Andon, N.L., et al. 1999. DANCE, a novel secreted RGD protein expressed in developing, atherosclerotic, and balloon-injured arteries. J. Biol. Chem. 274: 22476-22483.

Nelimarkka, L., Salminen, H., Kuopio, T., Nikkari, S., Ekfors, T., Laine, J., Pelliniemi, L., and Jarvelainen, H. 2001. Decorin is produced by capillary endothelial cells in inflammationassociated angiogenesis. Am. J. Pathol. 158: 345-353.

O'Connor, D.S., Schechner, J.S., Adida, C., Mesri, M., Rothermel, A.L., Li, F., Nath, A.K., Pober, J.S., and Altieri, D.C. 2000. Control of apoptosis during angiogenesis by survivin expression in endothelial cells. Am. J. Pathol. 156: 393-398.

Ozaki, H., Hla, T., and Lee, M.J. 2003. Sphingosine-1-phosphate signaling in endothelial activation. J. Atheroscler. Thromb. 10: $125-131$.

Paddison, P.J., Caudy, A.A., Bernstein, E., Hannon, G.J., and Conklin, D.S. 2002. Short hairpin RNAs (shRNAs) induce sequence-specific silencing in mammalian cells. Genes \& Dev. 16: 948-958.

Papapetropoulos, A., Fulton, D., Mahboubi, K., Kalb, R.G., O'Connor, D.S., Li, F., Altieri, D.C., and Sessa, W.C. 2000. Angiopoietin-1 inhibits endothelial cell apoptosis via the Akt/survivin pathway. J. Biol. Chem. 275: 9102-9105.

Potente, M., Fisslthaler, B., Busse, R., and Fleming, I. 2003. 11,12-Epoxyeicosatrienoic acid-induced inhibition of FOXO factors promotes endothelial proliferation by down-regulating p27Kip1. J. Biol. Chem. 278: 29619-29625. 
Ramaswamy, S., Nakamura, N., Sansal, I., Bergeron, L., and Sellers, W.R. 2002. A novel mechanism of gene regulation and tumor suppression by the transcription factor FKHR. Cancer Cell 2: 81-91.

Sato, T.N., Tozawa, Y., Deutsch, U., Wolburg-Buchholz, K., Fujiwara, Y., Gendron-Maguire, M., Gridley, T., Wolburg, H., Risau, W., and Qin, Y. 1995. Distinct roles of the receptor tyrosine kinases Tie-1 and Tie-2 in blood vessel formation. Nature 376: 70-74.

Serini, G., Valdembri, D., Zanivan, S., Morterra, G., Burkhardt, C., Caccavari, F., Zammataro, L., Primo, L., Tamagnone, L., Logan, M., et al. 2003. Class 3 semaphorins control vascular morphogenesis by inhibiting integrin function. Nature 424: 391-397.

Shindo, T., Manabe, I., Fukushima, Y., Tobe, K., Aizawa, K., Miyamoto, S., Kawai-Kowase, K., Moriyama, N., Imai, Y., Kawakami, H., et al. 2002. Kruppel-like zinc-finger transcription factor KLF5/BTEB2 is a target for angiotensin II signaling and an essential regulator of cardiovascular remodeling. Nat. Med. 8: 856-863.

Skurk, C., Maatz, H., Kim, H.S., Yang, J., Abid, M.R., Aird, W.C., and Walsh, K. 2003. The Akt-regulated forkhead transcription factor FOXO3a controls endothelial cell viability through modulation of the caspase-8 inhibitor FLIP. J. Biol. Chem. 279: 1513-1525.

St Croix, B., Rago, C., Velculescu, V., Traverso, G., Romans, K.E., Montgomery, E., Lal, A., Riggins, G.J., Lengauer, C., Vogelstein, B., et al. 2000. Genes expressed in human tumor endothelium. Science 289: 1197-1202.

Stoeltzing, O., Ahmad, S.A., Liu, W., McCarty, M.F., Wey, J.S., Parikh, A.A., Fan, F., Reinmuth, N., Kawaguchi, M., Bucana, C.D., et al. 2003. Angiopoietin-1 inhibits vascular permeability, angiogenesis, and growth of hepatic colon cancer tumors. Cancer Res. 63: 3370-3377.

Stratmann, A., Risau, W., and Plate, K.H. 1998. Cell type-specific expression of angiopoietin-1 and angiopoietin-2 suggests a role in glioblastoma angiogenesis. Am. J. Pathol. 153: 1459-1466.

Suri, C., Jones, P.F., Patan, S., Bartunkova, S., Maisonpierre, P.C., Davis, S., Sato, T.N., and Yancopoulos, G.D. 1996. Requisite role of angiopoietin-1, a ligand for the TIE2 receptor, during embryonic angiogenesis. Cell 87: 1171-1180.

Tang, E.D., Nunez, G., Barr, F.G., and Guan, K.L. 1999. Negative regulation of the forkhead transcription factor FKHR by Akt. J. Biol. Chem. 274: 16741-16746.

Tang, T.T., Dowbenko, D., Jackson, A., Toney, L., Lewin, D.A., Dent, A.L., and Lasky, L.A. 2002. The forkhead transcription factor AFX activates apoptosis by induction of the BCL-6 transcriptional repressor. J. Biol. Chem. 277: 14255-14265.

Thurston, G., Suri, C., Smith, K., McClain, J., Sato, T.N., Yancopoulos, G.D., and McDonald, D.M. 1999. Leakage-resistant blood vessels in mice transgenically overexpressing angiopoietin-1. Science 286: 2511-2514.

Tissir, F. and Goffinet, A.M. 2003. Reelin and brain development. Nat. Rev. Neurosci. 4: 496-505.

Tran, H., Brunet, A., Griffith, E.C., and Greenberg, M.E. 2003. The many forks in FOXO's road. Science STKE 2003: RE5.

Visconti, R.P., Richardson, C.D., and Sato, T.N. 2002. Orchestration of angiogenesis and arteriovenous contribution by angiopoietins and vascular endothelial growth factor (VEGF). Proc. Nat1. Acad. Sci. 99: 8219-8224.

Wang, B., Xiao, Y., Ding, B.B., Zhang, N., Yuan, X., Gui, L., Qian, K.X., Duan, S., Chen, Z., Rao, Y., et al. 2003. Induction of tumor angiogenesis by Slit-Robo signaling and inhibition of cancer growth by blocking Robo activity. Cancer Cell 4: 19-29.
Wei, Y., Harris, T., and Childs, G. 2002. Global gene expression patterns during neural differentiation of P19 embryonic carcinoma cells. Differentiation 70: 204-219.

Wong, A.L., Haroon, Z.A., Werner, S., Dewhirst, M.W., Greenberg, C.S., and Peters, K.G. 1997. Tie2 expression and phosphorylation in angiogenic and quiescent adult tissues. Circ. Res. 81: 567-574.

Yancopoulos, G.D., Davis, S., Gale, N.W., Rudge, J.S., Wiegand, S.J., and Holash, J. 2000. Vascular-specific growth factors and blood vessel formation. Nature 407: 242-248.

Zagzag, D., Hooper, A., Friedlander, D.R., Chan, W., Holash, J., Wiegand, S.J., Yancopoulos, G.D., and Grumet, M. 1999. In situ expression of angiopoietins in astrocytomas identifies angiopoietin-2 as an early marker of tumor angiogenesis. Exp. Neurol. 159: 391-400.

Zhang, X., Gan, L., Pan, H., Guo, S., He, X., Olson, S.T., Mesecar, A., Adam, S., and Unterman, T.G. 2002. Phosphorylation of serine 256 suppresses transactivation by FKHR (FOXO1) by multiple mechanisms. Direct and indirect effects on nuclear/cytoplasmic shuttling and DNA binding. J. Biol. Chem. 277: 45276-45284.

Zhang, L., Yang, N., Park, J.W., Katsaros, D., Fracchioli, S., Cao, G., O'Brien-Jenkins A., Randall, T.C., Rubin, S.C., and Coukos, G. 2003. Tumor-derived vascular endothelial growth factor up-regulates angiopoietin-2 in host endothelium and destabilizes host vasculature, supporting angiogenesis in ovarian cancer. Cancer Res. 63: 3403-3412. 


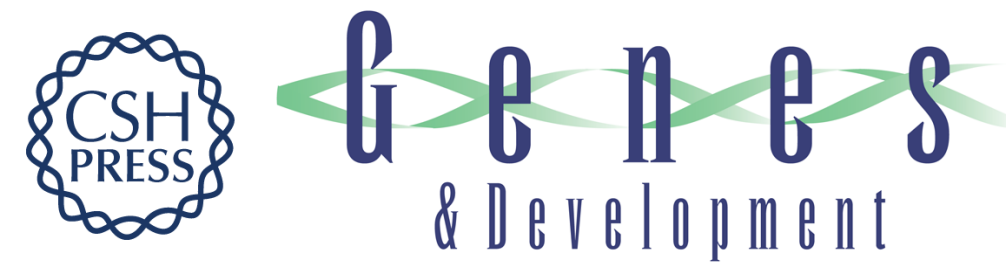

\section{Angiopoietin-1 modulates endothelial cell function and gene expression via the transcription factor FKHR (FOXO1)}

Christopher Daly, Vivian Wong, Elena Burova, et al.

Genes Dev. 2004, 18:

Access the most recent version at doi:10.1101/gad.1189704

Supplemental http://genesdev.cshlp.org/content/suppl/2004/04/23/18.9.1060.DC1
Material

References This article cites 52 articles, 23 of which can be accessed free at:

http://genesdev.cshlp.org/content/18/9/1060.full.html\#ref-list-1

License

Email Alerting Receive free email alerts when new articles cite this article - sign up in the box at the top

Service right corner of the article or click here.

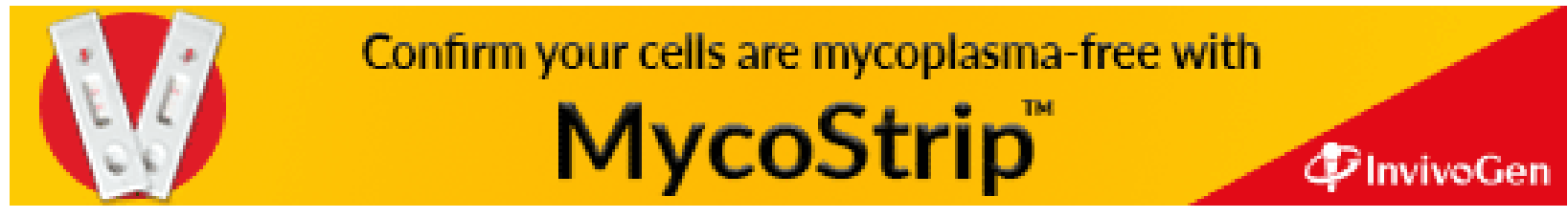

